\title{
An alternative mebendazole formulation for cystic echinococcosis: the treatment efficacy, pharmacokinetics and safety in mice
}

\author{
Cong-Shan Liu ${ }^{1}$, Hao-Bing Zhang ${ }^{1 *}$, Wen Lei ${ }^{2}$, Chao-Wei Zhang ${ }^{1}$, Bin Jiang ${ }^{1}$, Qi Zheng ${ }^{1}$, Jian-Hai Yin ${ }^{1}$
} and Xiu-Min Han²

\begin{abstract}
Background: Cystic echinococcosis is a serious zoonotic infection worldwide caused by metacestodes of Echinococcus gruanulosus. Mebendazole and albendazole are the only two drugs used in the treatment of this disease with cure rates only about $30 \%$ due to the poor oral absorption. Thus an alternative treatment for this disease is needed.
\end{abstract}

Methods: A mebendazole oily suspension (MBZ-OS) was prepared and orally administrated to mice infected with echinococcus cysts for 8 months at $12.5 \mathrm{mg} / \mathrm{kg}$ and $25 \mathrm{mg} / \mathrm{kg}$ for 14 consecutive days. Mebendazole suspended in $1 \%$ tragacanth (MBZ-1\% tragacanth) served as treated control. In addition, liver and serum samples were collected from these treated mice $(25 \mathrm{mg} / \mathrm{kg})$ for histopathology examination and liver function test. For pharmacokinetic analysis, plasma, parasite (cyst wall and cyst fluid) and tissue samples were collected at 0.25, 0.5, 1, 2, 4, 8, 16 and $24 \mathrm{~h}$ after orally administrating MBZ-OS and MBZ-1\% tragacanth to E. granulosus-infected mice at $25 \mathrm{mg} / \mathrm{kg}$. These samples were then processed and quantitatively analyzed by HPLC.

Results: The administration of MBZ-OS resulted in a treatment efficacy with the cyst weight reductions higher than $80 \%$, significantly better than the corresponding MBZ-1\% tragacanth groups. The better treatment efficacy of MBZ-OS was related to the higher drug concentration in plasma, parasites and tissues. It was also shown that the injury of the liver was not significantly altered by taking MBZ-OS compared to the untreated control.

Conclusion: These findings demonstrate that MBZ-OS is a promising new formulation of MBZ for treatment of hydatid diseases without showing significantly liver toxicity.

Keywords: Mebendazole oily suspension, Cystic echinococcosis, Treatment efficacy, Pharmacokinetics, Histopathology examination, Liver function test

\section{Background}

Cystic echinococcosis (CE) is a life-threatening disease with serious public health and economic concern worldwide. Infections with Echinococcus granulosus, the causative agent of $\mathrm{CE}$, occur globally and mostly in the Mediterranean area, South America, Russia, western China, Europe and Japan [1,2]. In China, with approximately 380,000 cases nationwide, $\mathrm{CE}$ is endemic in at

\footnotetext{
*Correspondence: zhang_haobing@163.com

'National Institute of Parasitic Diseases, Chinese Center for Disease Control and Prevention, Key Laboratory of Parasite and Vector Biology, MOH, WHO Collaborating Centre for Malaria, Schistosomiasis and Filariasis, Shanghai 200025, China

Full list of author information is available at the end of the article
}

least 23 provinces [3-5] and at least 50 million individuals are under the risk of this disease [6]. The proliferation of metacestodes mainly located in liver and lung, leading to the space-occupying lesions. However, the initial phase of the infection is always asymptomatic for many years or even permanently. Without effective treatment, the development of cysts will eventually result in organ malfunction and even death in many cases [7-9]. The preferred treatment strategies for CE are surgical resection of the parasite mass and puncture, aspiration, injection, re-aspiration (PAIR). The other option is chemotherapy with albendazole (ABZ) or mebendazole (MBZ), the only two drugs recommended by WHO. Both 
surgery and PAIR are usually combined with these two benzimidazoles, while chemotherapy is the only option in inoperable and recrudescent cases [9]. Moreover, for the great majority of patients in the resource-poor remote areas in China, anti-parasitic treatment remains the primary choice [10].

$\mathrm{ABZ}$ and $\mathrm{MBZ}$ are considered to have parasitocidal effect in vitro [11,12]. Nevertheless, according to the reports from the clinical trials, the cure rates of $\mathrm{MBZ}$ and $\mathrm{ABZ}$ in the treatment of $\mathrm{CE}$ were about $30 \%$ $[3,7,8,13-15]$. The unsatisfied therapeutic results are commonly attributed to the poor drug absorption rate which results in low drug concentartions in plasma and hydatid cysts after oral administration [16]. In addition, for MBZ, the inactive metabolites produced in the liver could be another possible reason contributing to the low active drug level [17]. In order to improve cure rate, these two benzimidazoles were recommended to be taken together with a fat-containing meal [9]. In some reports, suspending benzimidazoles in oils increased the solubility [18], the drug concentration in plasma, the bioavailability [18-22] and even the treatment efficacy for infected animals $[18,22,23]$. In China, the albendazole-emulsion was proved effective $[24,25]$ and has already been widely used in clinic. Due to the better effect of MBZ against E. granulosus metacestodes in vitro and in experimental therapy proceeded in mice than ABZ [11,12,26,27], a superior improvement of MBZ treatment efficacy could be achieved by increasing the bioavailability.

Until now, some progress has been achieved on the novel formulations of MBZ. Solid dispersion with polyethylene glycol $[28,29], \beta$-cyclodextrin compounds $(\beta-C D)$ [30], capsule [31] or drug-povidone complexes [16] were tested in rodents and showed enhanced bioavailabilities compared with the parent drugs. And the improving efficacy of solid dispersion with polyethylene glycol and drugpovidone complexes for $\mathrm{CE}$ was also confirmed in some studies [32,33]. However, these researches for MBZ formulations have not been continued and eventually translated into clinical applications. Based on our previous study [18], we prepared a MBZ oily suspension with oleic acid, glycerol trioleate, soy bean oil, some surfactants and preservatives in the present study. Subsequently, the treatment efficacy, the drug concentrations in plasma, parasite and tissues, and the influence on the liver were evaluated.

\section{Methods}

\section{Chemicals}

MBZ powder with the purity over $99.0 \%$ was purchased from Hanjiang Pharm. Co. (Hanzhong, China). MBZ standard and $\mathrm{ABZ}$ served as internal standard were purchased from Sigma-Aldrich Co. (St. Louis, UAS). The glycerol trioleate, oleic acid and soybean oil were provided by
Qianwei Oil Technology Co., Ltd. (Shanghai, China). All other chemicals were of the analytical pure grade.

\section{Parasites, animals and infection}

Liver hydatid cysts were obtained from newly slaughtered sheep at abattoirs in Xining, Qinghai province, China. Protoscoleces of E. granulosus were collected aseptically from the cysts, and kept in cyst fluid at $4^{\circ} \mathrm{C}$ for not more than 3-4 days before use. Prior to infection, the collected protoscoleces were rinsed 5-8 times with Hanks' balanced salt solution (HBSS) containing penicillin $(500 \mathrm{U} / \mathrm{ml})$ and streptomycin $(500 \mathrm{U} / \mathrm{ml})$. Viability of the PSCs was confirmed by visual inspection through inverted microscopy after staining by $0.1 \%$ methylene blue. A protoscoleces survival rate of more than $95 \%$ was necessary before the infection. Kunming strain mice were purchased from SLAC Laboratory Animal (Shanghai, China). Animals were kept at the animal facility and had free access to rodent food and tap water throughout the study. After one week acclimatization, the female mice with body weight of 18-22 g were inoculated intraperitoneally with 2,000 protoscoleces individually.

\section{Preparation of MBZ oily formulation}

The MBZ oily formulation (MBZ-OS) were prepared by suspending MBZ in the mixture of oleic acid, glycerol trioleate, soybean oil, span 80 , tween 80 and sorbic acid at a concentration of 2.5 and $1.25 \mathrm{~g} / \mathrm{l}(\mathrm{w} / \mathrm{v})$ respectively, while $\mathrm{MBZ}$ in $1 \%$ tragacanth (MBZ-1\% tragacanth) at the same concentration served as treated control. The volume of each drug preparation administered to mice was $10 \mathrm{ml} / \mathrm{kg}$. All the drug suspensions were made with bowl mill (Nanjing, China) at $220 \mathrm{rpm}$ for $1 \mathrm{~h}$.

\section{Effect against secondary cysts of $E$. granulosus}

Seventy-one mice inoculated with E. granulosus protoscoleces for 8 months were divided into 5 groups of 10-17 mice. Two groups were treated orally with MBZ-OS at a daily dose of $25 \mathrm{mg} / \mathrm{kg}$ and $12.5 \mathrm{mg} / \mathrm{kg}$ for 14 consecutive days respectively, and two groups were treated with MBZ-1\% tragacanth as the same scheme. The remaining one group of 17 mice infected but untreated served as control. Mice were sacrificed two weeks post-treatment. Then the cysts in the peritoneal cavity were isolated and removed for weighing. The efficacy was assessed by mean cyst weight and mean cyst weight reduction as previously described [18].

\section{Drug concentrations and pharmacokinetics of MBZ formulation}

Collection of plasma, cyst wall, cyst fluid and tissues samples

Forty-eight mice inoculated with E. granulosus protoscoleces for 8 months were divided into two groups, one was administered orally with MBZ-OS at a single dose of $25 \mathrm{mg} / \mathrm{kg}$, and the other was treated orally with the same 
dose of MBZ-1\% trangacanth. Subgroups of 3 mice in each group were bled at $0.25,0.5,1,2,4,8,16$ and $24 \mathrm{~h}$ post-administration. The plasma samples were collected after centrifugation at $2583 \mathrm{x}$ g for 15 minutes and then stored immediately at $-20^{\circ} \mathrm{C}$ pending HPLC analysis.

Then the hydatid cyst (parasite), heart, liver, spleen, lung, kidney, intestine and brain of each mouse were rapidly excised after blood collection at the same time intervals, while the cyst fluid was drawn from the hydatid cyst by syringe, and then stored at $-20^{\circ} \mathrm{C}$. The tissues were immediately washed twice with normal saline, wiped with filter paper, weighed and homogenized with $1.0 \mathrm{ml}$ of normal saline. The tissue samples were centrifuged at $2583 \mathrm{x} \mathrm{g}$ for 15 minutes. Then the supernatant was collected and then stored at $-20^{\circ} \mathrm{C}$.

\section{Quantitative analysis by HPLC}

For MBZ assay, $0.5 \mathrm{ml}$ plasma, cyst wall, cyst fluid and mice's tissue samples with $\mathrm{ABZ}$ as internal standard was extracted with Oasis HLB Cartridges (Waters, USA). The final collection of methanol elution was dried and redissolved in methanol. All samples were filtrated with $0.45 \mu \mathrm{m}$ membrane filter before injection.

The system of instrument consisted of a 1525 Binary HPLC Pumps, a 717 plus auto sampler and a 2457 Dual $\lambda$ Absorbance Detector (Waters, USA). The assay of MBZ was performed in a $5 \mu \mathrm{m} \mathrm{C}_{18} 250 \times 4.6 \mathrm{~mm}$ column (Beckman Coulter, USA) and a mobile phase containing $350 \mathrm{ml}$ of $0.05 \mathrm{M}$ ammonium sulfate and $650 \mathrm{ml}$ of methanol at a flow rate of $1 \mathrm{ml} / \mathrm{min}$. The MBZ concentration was measured by its absorbance at a wavelength of $289 \mathrm{~nm}$. The details and validation of the analytical methodology can be seen in Additional file 1.

\section{Pharmacokinetic parameters}

Using the non-compartmental model present in DAS 2.0 (Drug Analyze System, Shanghai University of T.C.M, China), the pharmacokinetic parameters of $\mathrm{AUC}_{0-\mathrm{t}}$ (the area under the drug concentration-time curve), $\mathrm{C}_{\max }$ (the peak concentration of the drug) and $\mathrm{T}_{\max }$ (time to the drug peak concentration) were estimated. The value of relative bioavailability (F) was calculated by the following formula:

$F=A U C_{0-t}$ of $M B Z-O S / A U C_{0-t}$ of $M B Z-1 \%$ trangacanth

Influence of MBZ-OS on the liver of E. granulosus-infected mice

\section{Liver function test}

Before the mice were sacrificed for evaluating the treatment effect of MBZ-OS against secondary cysts of E. granulosus, the blood sera of 10 mice respectively from MBZ-OS and MBZ-1\% trangacanth at a dose of $25 \mathrm{mg} / \mathrm{kg}$, and untreated control group were collected and immediately ready for the liver function test. In order to observe the liver injury of mice infected with E. granulosus cysts, the blood of normal mice, which were kept for the same 8 months was also collected and served as uninfected group. The liver function test was carried out by Adicon Clinical Laboratories (Shanghai, China) with Automatic Chemistry Analyzer 640 (OLYMPUS, Japan). The total protein (TP), albumin (ALB), globulin (GLB), total bilirubin (TBIL), direct bilirubin (DBIL), indirect bilirubin (IBIL), alkaline phosphatase (ALP), alanine transaminase (ALT), aspartate transaminase (AST) were analyzed with Automatic Chemistry Analyzer 640 (Olympus, Japan).

\section{Histopathology examination}

The livers of 5 mice from the same two treated groups, untreated control group and uninfected group corresponding to liver function tests were rapidly excised, washed twice with normal saline and fixed in $10 \%$ neutral buffered formal. The fixed samples were dehydrated in ascending series of ethanol, embedded in paraffin, cut into $5 \mu \mathrm{m}$ sections, and stained with hematoxylin and eosin $(\mathrm{H}+\mathrm{E})$ for microscopic examination. For statistical purposes, the severity of histopathological changes was measured on a semi-quantitative scale scored in four categories according to the intensity of alterations: without alteration (0), slightly altered (1), intermediately altered (2) and strongly altered (3).

\section{Statistical analysis}

The difference of mean cyst weight and liver function test results were analyzed by ANOVA in SPSS 17.0 and $P<0.05$ was considered statistically significant.

\section{Ethics approval}

Animal care and all animal procedures were carried out in compliance with the Guidelines for the Care and Use of Laboratory Animals produced by the Shanghai Veterinary Research Institute. The study was approved by the Ethics Committee of the Institute of Parasitic Diseases, Chinese Center for Disease Control and Prevention. The license number was IPD-2012-2.

\section{Results}

\section{Effect against secondary cysts of $E$. granulosus}

In the four groups orally treated with MBZ-OS and MBZ-1\% tragacanth at a daily dose of $12.5 \mathrm{mg} / \mathrm{kg}$ and $25 \mathrm{mg} / \mathrm{kg}$ for 14 days, the mean cyst weights were all lower than that of the untreated control. For MBZ-1\% tragacanth groups at $25 \mathrm{mg} / \mathrm{kg}$ and $12.5 \mathrm{mg} / \mathrm{kg}$, the cyst weight reductions were $48.9 \%$ and $2.2 \%$ respectively (Table 1). And the difference between MBZ-1\% tragacanth groups and untreated control groups was not statistically significant $(P>0.05)$. However, the mean 
cyst weights of MBZ-OS groups were significantly lower than that of the untreated control group $(P<0.05)$ with mean cyst weight reductions of $90.2 \%$ at $25 \mathrm{mg} / \mathrm{kg}$ and $82.6 \%$ at $12.5 \mathrm{mg} / \mathrm{kg}$ (Table 1). During the experiment, we had some inevitable loss due to the long- term administration. One mouse died in the MBZ-1\% tragacanth group at $12.5 \mathrm{mg} / \mathrm{kg}$ and one in the MBZ-OS group at $25 \mathrm{mg} / \mathrm{kg}$. But this did not affect the calculation of mean cyst weight.

\section{MBZ concentration in plasma, cyst fluid, cyst wall and tissues of mice}

It can be seen from Figure 1 that, both of the MBZ-OS and MBZ-1\% tragacanth were absorbed by the parasite and tissues of the mice. After orally administrating MBZ$1 \%$ tragacanth to mice at a single dose of $25 \mathrm{mg} / \mathrm{kg}$, a concentration peak of $0.27 \pm 0.15 \mu \mathrm{g} / \mathrm{ml}$ showed at $0.5 \mathrm{~h}$ post-treatment in the plasma, then the highest MBZ concentration of $0.49 \pm 0.23 \mu \mathrm{g} / \mathrm{ml}$ at $2 \mathrm{~h}$ (Figure 1). Thereafter, the MBZ concentration declined significantly and maintained at low level up to $24 \mathrm{~h}$. On the other hand, a concentration peak of $0.92 \pm 0.01 \mu \mathrm{g} / \mathrm{ml}$ and highest MBZ concentration of $3.28 \pm 0.40 \mu \mathrm{g} / \mathrm{ml}$ were emerged in plasma after oral administration of MBZ-OS. Obviously, the MBZ concentration in MBZ-OS group was higher than MBZ-1\% tragacanth. And in MBZ-OS group, the time reaching to the plasma peaks was somewhat delayed compared to MBZ-1\% tragacanth group.

Similar to that of the plasma, the peak concentration of MBZ-1\% tragacanth was $2.11 \pm 1.58 \mu \mathrm{g} / \mathrm{g}$ at $0.25 \mathrm{~h}$ and then maintained about $1 \mu \mathrm{g} / \mathrm{g}$ in hearts. The highest concentration $(2.59 \pm 0.68 \mu \mathrm{g} / \mathrm{g})$ of MBZ-OS emerged at $4 \mathrm{~h}$, and then slowly declined to about $1 \mu \mathrm{g} / \mathrm{g}$ (Figure 1 ).

As seen in Figure 1, the concentration-time profiles of cyst fluid and cyst wall were almost same. In detail, the first concentration peaks of $0.011 \pm 0.002 \mu \mathrm{g} / \mathrm{ml}$ and $0.70 \pm 0.3 \mu \mathrm{g} / \mathrm{g}$ had been detected in cyst fluid and cyst wall after $1-2 \mathrm{~h}$ post-administration after administrating MBZ-1\% tragacanth, and then the second peaks at $8 \mathrm{~h}$ $(0.006 \pm 0.001 \mu \mathrm{g} / \mathrm{ml}$ and $0.30 \pm 0.27 \mu \mathrm{g} / \mathrm{g}$, respectively). In contrast, the MBZ concentration of MBZ-OS increased with time and the highest concentration peaks of $0.031 \pm$ $0.004 \mu \mathrm{g} / \mathrm{ml}$ and $0.73 \pm 0.27 \mu \mathrm{g} / \mathrm{g}$ emerged at $8 \mathrm{~h}$ in cyst fluid and cyst wall. Thereafter, the drug levels declined but still higher than MBZ-1\% tragacanth till the end of the experiment period.

In the liver, the highest $\mathrm{MBZ}$ concentrations of MBZ-OS and MBZ-1\% tragacanth were $2.16 \pm 3.32 \mu \mathrm{g} / \mathrm{g}$ and $3.25 \pm 4.33 \mu \mathrm{g} / \mathrm{g}$ at $0.25 \mathrm{~h}$. Then the second concentration peaks of $1.12 \pm 0.56 \mu \mathrm{g} / \mathrm{g}$ and $1.71 \pm 0.74 \mu \mathrm{g} / \mathrm{g}$ were found at $2 \mathrm{~h}$ and $8 \mathrm{~h}$ post-administration. According to the concentration-time profile of the lung, the highest drug concentration of MBZ-1\% tragacanth was $9.05 \pm$ $13.21 \mu \mathrm{g} / \mathrm{g}$, and $40.8 \pm 30.28 \mu \mathrm{g} / \mathrm{g}$ at $2 \mathrm{~h}$ for MBZ-OS. During the $24 \mathrm{~h}$ post-administration, the drug concentrations of MBZ-OS were higher than that of MBZ-1\% tragacanth in spleen and kidney, with a delayed time reaching the drug peak concentration (Figure 1). The peak concentration of MBZ-1\% tragacanth was $0.30 \pm 0.32 \mu \mathrm{g} / \mathrm{g}$ at $2 \mathrm{~h}$ and then decreased in the brain. For MBZ-OS, there were two concentration peaks $(0.13 \pm 0.02 \mu \mathrm{g} / \mathrm{g}$ at $2 \mathrm{~h}$ and the second $0.47 \pm 0.03 \mu \mathrm{g} / \mathrm{g}$ at $8 \mathrm{~h}$ ).

In contrast to the plasma, parasite and other tissues, the drug concentration of MBZ-1\% tragacanth (38.3 \pm $44.01 \mu \mathrm{g} / \mathrm{g}$ ) in intestine was higher than that of MBZ-OS $(5.04 \pm 3.68 \mu \mathrm{g} / \mathrm{g})$. And at the end of $24 \mathrm{~h}$, the drug concentration of MBZ-OS group declined to $0.01 \pm 0.00 \mu \mathrm{g} / \mathrm{g}$ while that of MBZ-1\% tragacanth was still as high as $2.47 \pm 1.38 \mu \mathrm{g} / \mathrm{g}$.

\section{Pharmacokinetic parameters of plasma, cyst fluid, cyst wall and tissues of mice}

According to the MBZ concentration-time curve obtained from E. granulosus-infected mice orally administrated with MBZ formulations at a single dose of $25 \mathrm{mg} / \mathrm{kg}$, $\mathrm{T}_{\max }, \mathrm{C}_{\max }, \mathrm{AUC}_{0-\mathrm{t}}$ and $\mathrm{F}$ were calculated and listed in Table 2. In plasma, $\mathrm{T}_{\max }$ values of MBZ-OS and MBZ-1\% tragacanth were $2.6 \pm 1.1 \mu \mathrm{g} / \mathrm{ml}$ and $3.3 \pm 1.1 \mu \mathrm{g} / \mathrm{ml}$, respectively. But for parasite and tissues, the mean $T_{\max }$ values were numerically different between two treated groups. It was found that the $\mathrm{C}_{\max }$ values in the MBZ-OS group were 0.3-4.9 times higher than the MBZ-1\% tragacanth group in plasma, cyst fluid, liver, lung, spleen, brain, nearly the same in kidney and 0.6-4.6 times lower in cyst wall and intestine. In addition, the AUC values were 1.5-9.3 times of the MBZ-1\% tragacanth group in plasma, parasite and most tissues but not intestine.

Table 1 Mean \pm SD $(\mathrm{g})$ and reduction (\%) of the hydatid cysts weigh recovered from infected mice from the untreated control and treated groups MBZ-1\% and MBZ-OS both dosed at 12.5 and $25 \mathrm{mg} / \mathrm{kg}$ daily during 14 days

\begin{tabular}{lllll}
\hline Groups & Dose $\mathbf{( m g / k g}$ per day $\times \mathbf{1 4}$ days) & No. of mice & Mean cyst weight $\mathbf{g}$ (SD) & Reduction of cyst weight (\%) \\
\hline Untreated control & - & 17 & $0.92(1.22)$ & 48.9 \\
MBZ-1\% tragacanth & 25 & 16 & $0.47(0.69)$ & 2.2 \\
& 12.5 & 16 & $0.90(1.15)$ & 90.2 \\
MBZ-OS & 25 & 10 & $0.09(0.07)^{*}$ & 82.6 \\
\hline
\end{tabular}

${ }^{*} P<0.05$ vs. untreated control. 

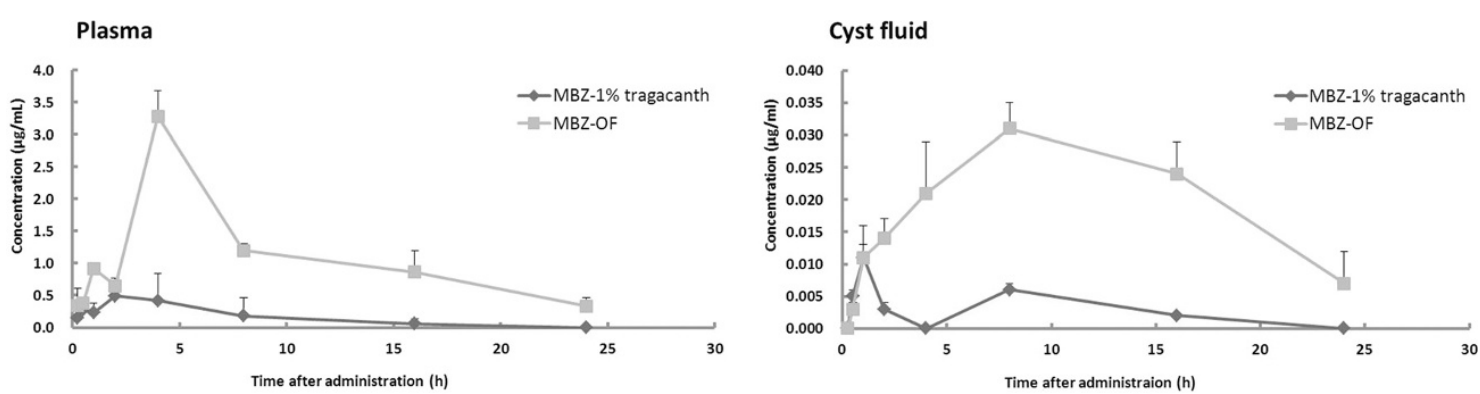

Cyst wall
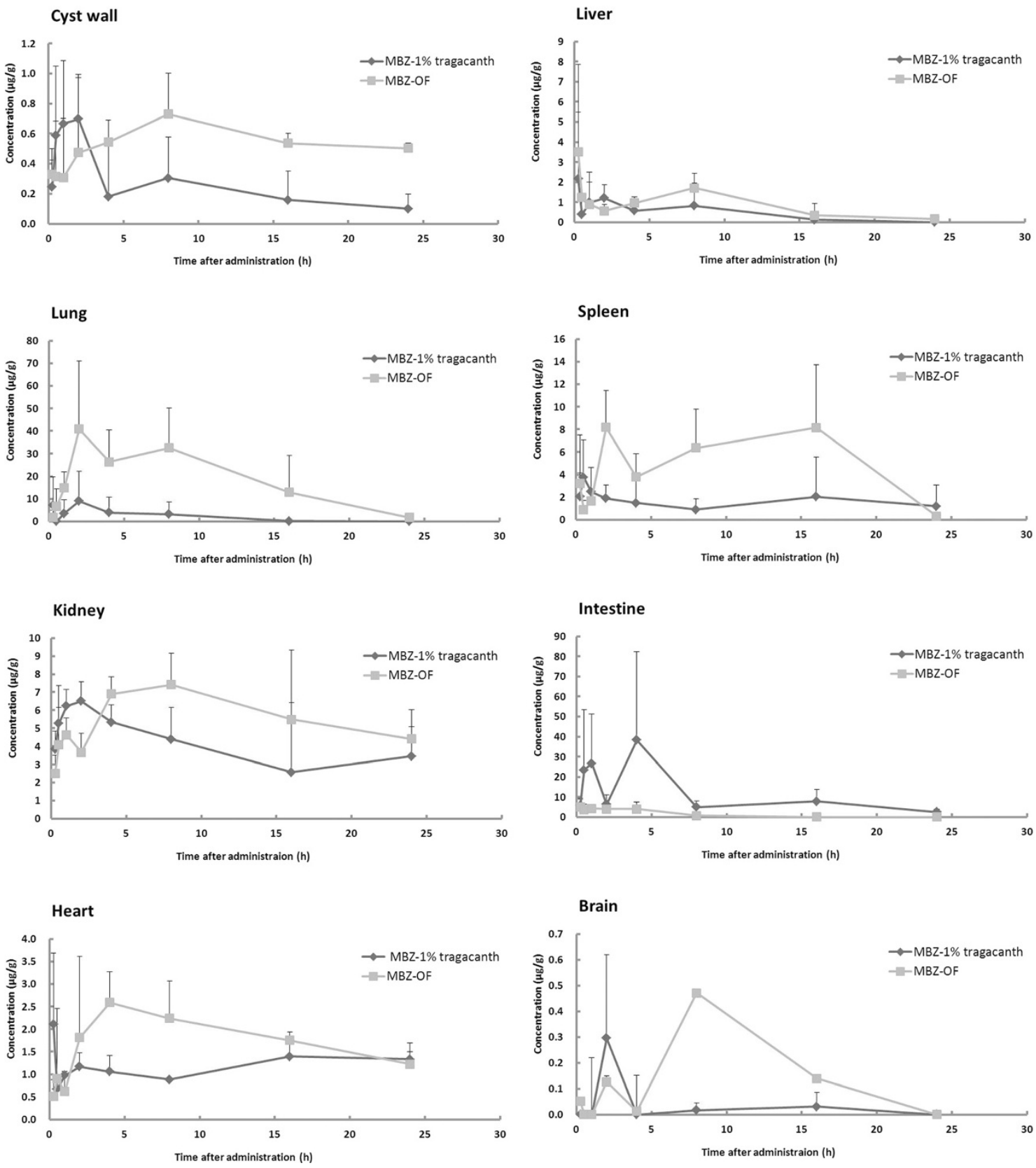

Figure 1 Mebendazole (MBZ) concentration in plasma and tissues of E. granulosus infected mice orally administrated with MBZ-OS and MBZ-1\% tragacanth at a single dose of $25 \mathrm{mg} / \mathrm{kg}$. 
Table 2 Pharmacokinetic parameters of MBZ-OS and MBZ-1\% tragacanth in plasma and tissues of mice after oral administration at a single dose of $25 \mathrm{mg} / \mathbf{k g}$

\begin{tabular}{|c|c|c|c|c|c|c|c|c|}
\hline \multirow{2}{*}{\multicolumn{2}{|c|}{$\begin{array}{l}\text { Plasma, Parasite } \\
\text { and Tissues }\end{array}$}} & \multicolumn{7}{|c|}{ Mean value (SD) of pharmacokinetic parameters (MBZ-1\% tragacanth/MBZ-OS) } \\
\hline & & \multicolumn{2}{|l|}{$\mathrm{T}_{\max }^{\mathrm{a}}(\mathrm{h})$} & \multicolumn{2}{|c|}{$C_{\max }{ }^{b}(\mu g / m l$ or $\mu g / g)$} & \multicolumn{2}{|c|}{ AUC $_{0-\mathrm{t}}{ }^{\mathrm{c}}(\mu \mathrm{g} / \mathrm{ml} \times \mathrm{h}$ or $\mu \mathrm{g} / \mathrm{g} \times \mathrm{h})$} & \multirow{2}{*}{$\frac{\mathbf{F}^{\mathbf{d}}}{7.1}$} \\
\hline Plasma & & $2.6(1.1)$ & $3.3(1.1)$ & $0.7(0.2)$ & $4.1(1.7)$ & $3.8(1.9)$ & $27.1(0.9)$ & \\
\hline \multirow[t]{2}{*}{ Parasite } & Cyst wall & $0.8(0.3)$ & $6.7(2.3)$ & $1.1(0.7)$ & $0.7(0.3)$ & $5.8(2.0)$ & $13.4(4.1)$ & 2.3 \\
\hline & Cyst fluid & $1.0(0)$ & $8.0(0)$ & $0.011(0.002)$ & $0.031(0.004)$ & $0.069(0.011)$ & $0.50(0.03)$ & 7.3 \\
\hline \multirow[t]{7}{*}{ Tissues } & Liver & $1.1(0.9)$ & $3.1(4.3)$ & $3.1(2.7)$ & $4.1(3.8)$ & $10.9(11.1)$ & $19.4(3.6)$ & 1.8 \\
\hline & Lung & $7.3(7.5)$ & $4.0(3.4)$ & $12.1(12.0)$ & $50.2(14.2)$ & $49.6(47.6)$ & 459.7 (133.1) & 9.3 \\
\hline & Spleen & $2.1(1.8)$ & $11.3(8.1)$ & $4.7(2.1)$ & $10.6(1.4)$ & $37.5(28.0)$ & $135.3(49.5)$ & 3.6 \\
\hline & Kidney & $1.2(0.8)$ & $9.2(6.1)$ & $7.3(2.1)$ & $7.6(2.0)$ & $94.1(24.4)$ & $137.8(38.9)$ & 1.5 \\
\hline & Intestine & $3.0(1.7)$ & $1.1(0.9)$ & $44.0(39.2)$ & $7.8(1.8)$ & $256.2(233.9)$ & $28.2(13.6)$ & 0.1 \\
\hline & Heart & $13.4(12.1)$ & $3.5(4.0)$ & $2.4(1.4)$ & $3.3(0.6)$ & $28.2(4.0)$ & $43.9(4.1)$ & 1.6 \\
\hline & brain & $8.7(7.0)$ & $6.0(3.5)$ & $0.2(0.3)$ & $0.5(0.1)$ & $0.7(0.3)$ & $3.8(0.06)$ & 5.4 \\
\hline
\end{tabular}

a: $T_{\max }$ was time to the drug peak concentration.

$\mathrm{b}: \mathrm{C}_{\max }$ was the peak concentration of the drug.

c: $A \cup C_{0-t}$ was the area under the drug concentration-time curve.

$\mathrm{d}: \mathrm{F}$ (relative bioaviability) $=\mathrm{AUC}_{0-\mathrm{t}}$ of $\mathrm{MBZ}-1 \%$ tragacanth/AUC $\mathrm{C}_{0-\mathrm{t}}$ of MBZ-OS.

Influence of MBZ-OS on the liver of mice Histopathological changes of the liver

After the treatment with MBZ-OS and MBZ-1\% tragacanth at $25 \mathrm{mg} / \mathrm{kg}$, histopathological changes in the liver of the normal (uninfected), untreated and treated mice were observed simultaneously (Figure 2, Table 3). Compared with uninfected groups, there was no significant difference from other groups in histopathological changes $(P>0.05$, Table 3$)$. In uninfected and untreated control groups, the hepatocytes and other cells of the livers were normal and systematically arranged but showed light fatty infiltration. However, fatty infiltration had been seen in all groups without significant difference. The light swelling of hepatocytes was only found in the two treated groups (Figure 2).

\section{Liver function test}

As seen in Table 4, the liver function test results suggested that the IBIL values of the untreated control group and two treated groups were all significantly increased compared with the uninfected group. In addition, the AST and ALT values of the untreated control group were also significantly higher than that of the uninfected group. However, after the treatment with MBZ-OS or MBZ-1\% tragacanth, the values of these two parameters (AST and ALT) were decreased and reached to the level of the uninfected control. It was also found that the GLB value of the MBZ-OS was $28.3 \pm 2.4 \mathrm{~g} / \mathrm{L}$, significantly higher than that of the other groups.

\section{Discussion}

In our previous studies, it was found that, due to the increase of the drug solubility, suspending the insoluble MBZ with oily solvents significantly improved the treatment efficacy against secondary E. granulosus cysts than MBZ-1\% tracangth [18]. Then the optimal MBZ oily suspension was chosen by comparing the pharmacokinetic parameters, especially the values of $\mathrm{C}_{\max }$ and $\mathrm{AUC}_{0-\mathrm{t}}$ (unpublished). At a dose of $25 \mathrm{mg} / \mathrm{kg}$ and $12.5 \mathrm{mg} / \mathrm{kg}$, the cyst weight reductions of the MBZ-OS groups were higher than $80 \%$, while $\mathrm{MBZ}-1 \%$ tragacanth was lower than $30 \%$. In some studies, $25 \mathrm{mg} / \mathrm{kg}$ was considered as the minimum effective dose for MBZ in the treatment of mice infected with E. granulosus cysts $[26,34]$. However, the lower dosage used in this study made it possible to reduce the oral dose of MBZ-OS in the future clinical trials. At present, the current solid tablet of MBZ is sub-optimal in efficacy, resulting in the need for higher doses and prolonged duration of treatment (40 mg/kg-50 mg/kg per day in three divided doses for at least 3-6 months) [9]. With such long term chemotherapy, the patients hardly continue the treatment as they are more likely to comply with ABZ because it is more cost-effective and involves fewer tablets. However, in view of the fact that the effect of MBZ against E. granulosus metacestodes in vitro and in experimental therapy proceeded in mice were both better than ABZ [11,12,26,27], it could be concluded that once the absorption problem of MBZ is solved, MBZ would be more widely used with improved clinical cure rate.

The results from the pharmacokinetic analysis of MBZ in plasma, parasite and tissues of mice proved that the improved treatment efficacy was resulted from the higher drug concentration in plasma and parasite. Because of the special structure of the hydatid cysts, MBZ could penetrate these cysts by passive diffusion only [11]. Therefore, the drug concentrations in cyst fluid and cyst wall were determined by that in the plasma. And in 
Table 3 Histopathological changes in the livers of the mice from the uninfected control, untreated control and treated groups MBZ-1\% tragacanth and MBZ-OS (10 mice per group) were observed by microscopy $(n=5)$

\begin{tabular}{lllll}
\hline Histopathologcial Changes & Uninfected control group & Untreated control group & MBZ-1\% tragacanth & MBZ-OS \\
\hline Congestion & $0.0(0.0)$ & $0.0(0.0)$ & $0.0(0.0)$ & $0.0(0.0)$ \\
Fatty infiltration & $0.4(0.3)$ & $0.8(0.5)^{*}$ & $0.6(0.6)$ & $0.6(0.6)$ \\
Hepatocyte swelling & $0.0(0.0)$ & $0.0(0.0)$ & $0.5(0.7)$ & $0.4(0.6)$ \\
Inflammatory cell infiltration & $0.0(0.0)$ & $0.0(0.0)$ & $0.0(0.0)$ & $0.0(0.0)$ \\
\hline
\end{tabular}

${ }^{*} P<0.05$ vs. uninfected group.

MBZ-OS groups, both of the drug levels in plasma and parasite increased. That was, the $\mathrm{AUC}_{0-\mathrm{t}}$ values of plasma, cyst fluid and cyst wall were 7.1, 7.3 and 2.3 times of that in MBZ-1\% tracangth group, while the $\mathrm{C}_{\max }$ values were $5.9,2.8$ and 0.6 times respectively. It was also found that the MBZ concentration in cyst fluid was obviously lower than in plasma after a single administration of MBZ-OS. However, drug concentration in cyst fluid would be closed to that in plasma by continued chemotherapy, so the long time regime is necessary [35]. In addition, the increased $\mathrm{AUC}_{0-\mathrm{t}}$ values of cyst fluid and cyst wall in MBZ-OS group were partially due to the prolonged $\mathrm{T}_{\max }$.

In this study, the pharmacokinetic analysis was proceeded with E. granulosus -infected mice. And the calculated pharmacokinetic parameters were numerically different from that of the uninfected mice from our former studies [18]. In details, the $\mathrm{C}_{\max }$ and $\mathrm{AUC}_{0-\mathrm{t}}$ values of infected mice were lower than that of uninfected mice with prolonged $\mathrm{T}_{\max }$. Similarly, Witassek et al. reported the MBZ plasma concentration of the E. multilocularis-infected jirds was lower than the non-infected ones [36]. It seems that the $E$. granulosus infection might influence the MBZ metabolism in mice. However, the mechanism would be clarified by further study on this topic. In our previous studies, the $\mathrm{T}_{\max }$ values of MBZ oily suspensions changed a little compared with the MBZ-1\% tracangth [18]. These results suggested that the absorption rate which is relevant to the value of $\mathrm{T}_{\max }$, still limit the absorption of MBZ into the plasma.

After oral administration of MBZ-OS, the drug concentrations in lung, spleen kidney, heart and brain were higher than that of the MBZ-1\% tragacanth. However, contributed by the accumulated indissolvable parent drug, the $C_{\max }$ value of MBZ-1\% tragacanth was nearly 6 times of the new formulation in the intestine. On the other
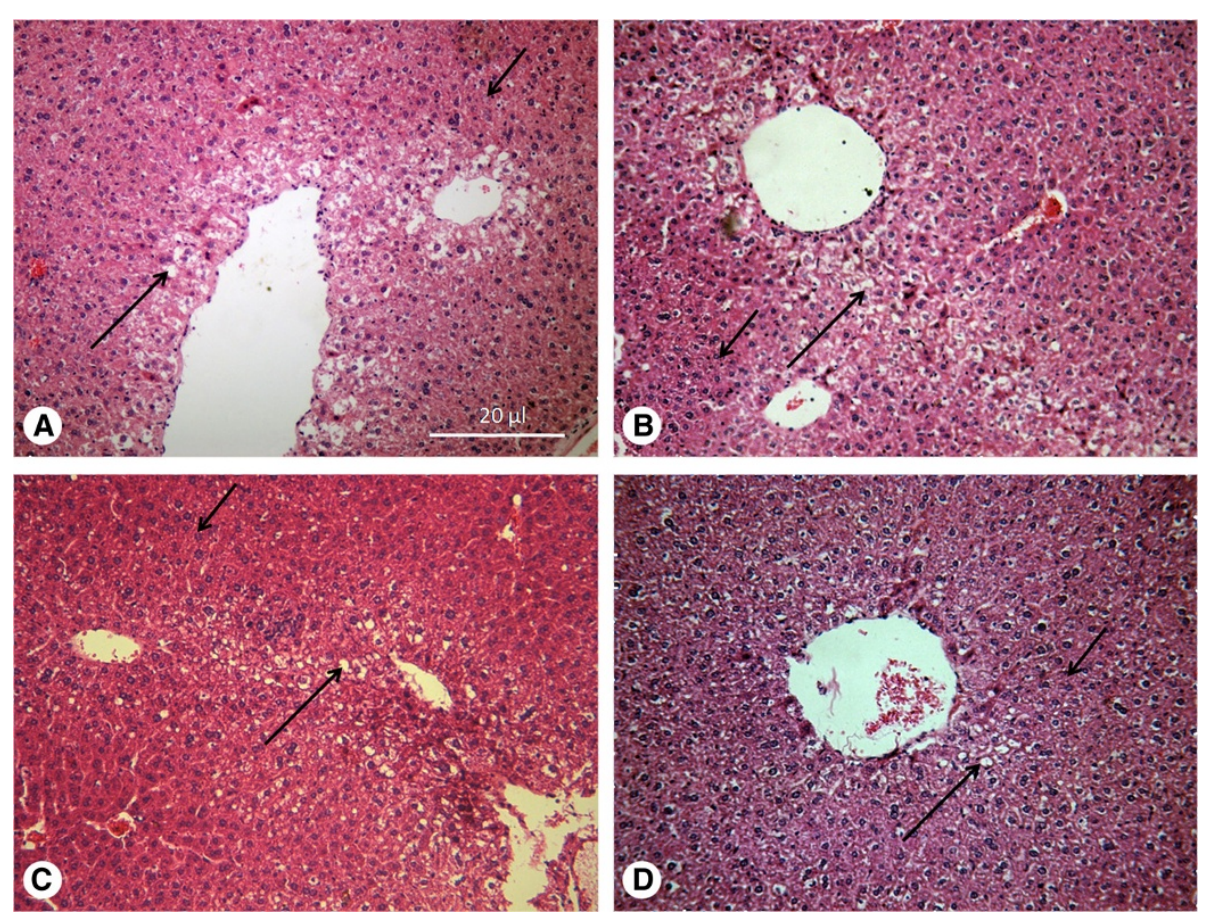

Figure 2 Histopathological changes of liver. $\mathrm{H}+\mathrm{E}$, fatty infiltration (large arrow), hepatocyte swelling (small arrow) A. Normal mice; B. E. granulosus infected mice without treatment; C. E. granulosus infected mice treated with MBZ-1\% tragacanth; D. E. granulosus infected mice treated with MBZ-OS. 
Table 4 Outcomes of liver function tests for mice from the uninfected control, untreated control and treated groups MBZ-1\% tragacanth and MBZ-OS (10 mice per group)

\begin{tabular}{|c|c|c|c|c|c|c|}
\hline Parameters & Definitions & Units & Uninfected control & Untreated control & MBZ-1\% tracangth & MBZ-OS \\
\hline T-BIL & Total bilirubin & umol/L & $2.3(0.8)$ & $2.8(0.4)$ & $3.2^{*}(0.8)$ & $2.9(0.5)$ \\
\hline D-BIL & Direct bilirubin & umol/L & $0.5(0.3)$ & $0.3(0.1)$ & $0.4(0.2)$ & $0.3(0.1)$ \\
\hline I-BIL & Indirect bilirubin & umol/L & $1.8^{* *}(0.7)$ & $2.6^{*}(0.4)$ & $2.8^{*}(0.7)$ & $2.6^{*}(0.5)$ \\
\hline $\mathrm{TP}$ & Total protein & $g / L$ & $55.2(1.9)$ & $57.7(2.9)$ & $58.2(3.8)$ & $63.1^{* *}(3.2)$ \\
\hline ALB & Albumin & $g / L$ & $31.6(1.7)$ & $32.2(1.6)$ & $32.7(2.0)$ & $34.8(2.0)$ \\
\hline GLB & Globulin & $g / L$ & $23.6(0.8)$ & $25.6(3.3)$ & $25.5(3.0)$ & $28.3^{* *}(2.4)$ \\
\hline$A / G$ & & & $1.3(0.1)$ & $1.3(0.2)$ & $1.3(0.2)$ & $1.2(0.4)$ \\
\hline AST & Aspartate transaminase & $\mathrm{U} / \mathrm{L}$ & $122.8^{* *}(32.1)$ & $173.7^{*}(107.0)$ & $113.9^{* *}(16.9)$ & $100.8^{* *}(14.7)$ \\
\hline ALT & Alanine transaminase & $U / L$ & $45.1^{* *}(21.8)$ & $81.0^{*}(48.8)$ & $35.7^{* *}(17.7)$ & $27.6 * *(4.5)$ \\
\hline AST/ALT & & & $3.0(0.8)$ & $2.3(0.7)$ & $3.6 * *(1.2)$ & $3.7^{* *}(0.7)$ \\
\hline ALP & Alkaline phosphatase & $U / L$ & $86.2(29.6)$ & $67.4(14.0)$ & $74.5(28.8)$ & $80.7(19.1)$ \\
\hline
\end{tabular}

${ }^{*} P<0.05$ vs. uninfected group.

${ }^{* *} P<0.05$ vs. untreated control group.

hand, MBZ-OS promoted more MBZ into the systemic circulation. It was found that the $\mathrm{C}_{\max }$ and $\mathrm{AUC}_{0-\mathrm{t}}$ values of MBZ-OS in liver and kidney were not changed as much as in plasma. As the crucial metabolism and elimination organs, liver and kidney might clear away MBZ by their corresponding functions. However, in lung, spleen and brain, $\mathrm{C}_{\max }$ and $\mathrm{AUC}_{0-\mathrm{t}}$ of $\mathrm{MBZ}-\mathrm{OS}$ were significantly increased than MBZ-1\% tragacanth. Given that the high drug concentration in tissues may bring some safety concern, MBZ-OS was orally given to 10 mice ( 5 female mice and 5 male mice) at $5 \mathrm{~g} / \mathrm{kg}$. After 7 days' observation, no mice died. Although no acute toxicity of MBZ-OS had been seen in this experiment, a long-term toxicity test is still necessary in the following study.

In the treatment of hydatid diseases, the benzimidazoles were considered safe with occasional side effects [37-39]. In China, albendazole-emulsion is the dominant clinical formulation for patients with echinococcosis. However, patients often feel uncomfortable in the liver after taking albendazole-emulsion on a daily basis. This may be due to the drug side effects or oils added in formulation. Considering that oils were also added in MBZ-OS, then the influence of this MBZ new formulation on the liver of mice was also observed in this study. At $25 \mathrm{mg} / \mathrm{kg}$, the hepatocytes of mice showed light fatty infiltration in all the experimental groups and the light swelling was found in both of the treated groups. So it was suggested that the long term taking of MBZ affected the hepatocytes. But comparing with the uninfected group, the changes were not significant. Hence, it could be preliminary concluded that the liver of mice were not seriously injured by taking MBZ and MBZ-OS than the raw materials. In order to obtain more information about liver toxicity, the liver function test was carried out by collecting the serum of the uninfected, the untreated control, MBZ-1\% tragacanth and MBZ-OS group. Unlike the results from the histopathological changes, some parameters showed significantly difference between uninfected group and the other groups. In details, the values I-BIL, AST and ALT of infected mice without treatment were statistically higher than that of uninfected mice. And the orally administration with MBZ did not change the increased I-BIL values but reduced the values of AST and ALT. In addition, the GLB values of the MBZ-OS were significantly increased after taking MBZ-OS. Due to the lack of the normal ranges for KM mice, the real injury of the liver could not be concluded from the liver function test. However, if the significant differences of these parameters between uninfected mice and infected could make sense, I-BIL, AST and ALT values might be used as the indicators for diagnosing the hydatid diseases. But this assumption needed verification with abundant clinical cases.

\section{Conclusion}

In the present study, a promising new formulation of MBZ for treatment of hydatid diseases was developed. This MBZ-OS improved the treatment efficacy in $E$. granulosus-infected mice and no serious injury on the liver was observed. However, based on the increased MBZ concentration, the lung and spleen toxicity should be paid more attention in a future study. For the clinical trials in healthy volunteers and patients, further researches will be required to apply under the support of government and pharmaceutical companies.

\section{Additional file}

Additional file 1: Supporting information, Figure S1-S2 and Table S1-S3. An Alternative Mebendazole Formulation for Cystic Echinococcosis: the

Treatment Efficacy, the Pharmacokinetics and the Safety on mice. 


\section{Abbreviations}

MBZ-OS: Mebendazole oily suspension; MBZ-1\% tragacant: Mebendazole suspended in 1\% tragacanth; CE: Cystic echinococcosis; PAIR: Puncture, aspiration, injection, re-aspiration; ABZ: Albendazole; MBZ: Mebendazole; $A \cup C_{0-t}$ : The area under the drug concentration-time curve; $C_{\text {max }}$ : The peak concentration of the drug; $T_{\text {max }}$ : Time to the drug peak concentration; F: Relative bioavailability; TP: Total protein; ALB: Albumin; GLB: Globulin; TBIL: Total bilirubin; DBIL: Direct bilirubin; IBIL: Indirect bilirubin; ALP: Alkaline phosphatase; ALT: Alanine transaminase; AST: Aspartate transaminase; $H+$ E: Hematoxylin and eosin.

\section{Competing interests}

The authors declare that they have no competing interests.

\section{Authors' contributions}

CSL and HBZ participated in the conception and design of the study and wrote the manuscript. CSL, CWZ, WL, BJ, QZ and XMH were involved in the experiment. JHY helped with statistical analysis and contributed to the manuscript. All authors read and approved the manuscript.

\section{Acknowledgments}

The authors cordially acknowledge the expert help of Professor Shu-Hua Xiao. This work was supported by the following grants: technology development research for science research institute (2014DFA31130), International S\&T cooperation (2010DFA33970) and the youth project of Shanghai Municipal Health Bureau (2012Y087).

\section{Author details}

1 National Institute of Parasitic Diseases, Chinese Center for Disease Control and Prevention, Key Laboratory of Parasite and Vector Biology, MOH, WHO Collaborating Centre for Malaria, Schistosomiasis and Filariasis, Shanghai 200025, China. ${ }^{2}$ Qinghai Institute for Endemic Disease Prevention and Control, Xining 811602, Qinghai, China.

Received: 29 May 2014 Accepted: 4 December 2014

Published online: 10 December 2014

\section{References}

1. Eckert J, Deplazes P: Biological, epidemiological, and clinical aspects of echinococcosis, a zoonosis of increasing concern. Clin Microbiol Rev 2004, 17:107-135.

2. Eckert J, Conraths FJ, Tackmann K: Echinococcosis: an emerging or re-emerging zoonosis? Int J Parasitol 2000, 30:1283-1294.

3. Jiang CP: Preliminary clinical obserations on mebendazole and traditional Chinese medicine treatment in 57 cases with echinococcosis. Chin J Parasitol Parasit Dis 1996, 4:209-210.

4. Wang LY, Wu WP, Zhu XH: The endemic status of hydatidosis in China from 2004 to 2008. Chin J Zoonoses 2010, 26:699-702.

5. Yang YR, Clements AC, Gray DJ, Atkinson JA, Williams GM, Barnes TS, McManus DP: Impact of anthropogenic and natural environmental changes on Echinococcus transmission in Ningxia Hui Autonomous Region, the People's Republic of China. Parasit Vectors 2012, 5:146.

6. Chai JJ: Echinococcosis control in China: challenges and research needs. Chin J Paraasitol Parasitic Dis 2009, 27:379-383.

7. Davis A, Dixon H, Pawlowski ZS: Multicentre clinical trials of benzimidazole-carbamates in human cystic echinococcosis (phase 2). Bull World Health Organ 1989, 67:503-508.

8. Davis A, Pawlowski ZS, Dixon H: Multicentre clinical trials of benzimidazolecarbamates in human echinococcosis. Bull World Health Organ 1986, 64:383-388.

9. Eckert J, Gemmell MA, Meslin FX, Pawlowski ZS: WHO/OIE Manual on echinococcosis in humans and animals: a public health problem of global concern. Paris: Office International des Epizooties 2001, 21-72.

10. Li T, Ito A, Pengcuo R, Sako Y, Chen X, Qiu D, Xiao N, Craig PS: Posttreatment follow-up study of abdominal cystic echinococcosis in tibetan communities of northwest Sichuan Province, China. PLOS Negl Trop Dis 2011, 5:e1364.

11. Yang $Y Q$, Zhang CW, Xiao SH: Histological comparison of the effect of praziquantel, mebendazole and albendazole on Echinococcus granulosus cyst in vivo and in vitro. Endem Dis Bull 1990, 5:17-20.
12. Morris $D L$, Chinnery JB, Ubhi $C$ : $A$ comparison of the effects of albendazole, its sulphone metabolite, and mebendazole on the viability of protoscoleces of Echinococcus granulosus in an in vitro culture system. Trans R Soc Trop Med Hyg 1987, 81:804-806.

13. Eckert J, Pawlowski Z, Dar FK, Vuitton DA, Kern P, Savioli L: Medical aspects of echinococcosis. Parasitol Today 1995, 11:273-276.

14. Horton RJ: Albendazole in treatment of human cystic echinococcosis: 12 years of experience. Acta Trop 1997, 64:79-93.

15. Vutova K, Mechkov G, Vachkov P, Petkov R, Georgiev P, Handjiev S, Ivanov A, Todorov T: Effect of mebendazole on human cystic echinococcosis: the role of dosage and treatment duration. Ann Trop Med Parasitol 1999, 93:357-365.

16. Daniel-Mwambete K, Torrado S, Cuesta-Bandera C, Ponce-Gordo F, Torrado $\mathrm{JJ}$ : The effect of solubilization on the oral bioavailability of three benzimidazole carbamate drugs. Int J Pharm 2004, 272:29-36.

17. Schantz PM, Van den Bossche H, Eckert J: Chemotherapy for larval echinococcosis in animals and humans: report of a workshop. $Z$ Parasitenkd 1982, 67:5-26.

18. Liu CS, Zhang HB, Jiang B, Yao JM, Tao Y, Xue J, Wen AD: Enhanced bioavailability and cysticidal effect of three mebendazole-oil preparations in mice infected with secondary cysts of Echinococcus granulosus. Parasitol Res 2012, 111:1205-1211.

19. Lur'e AA, Shcherbakov AM: Use of mebendazole in a mixture with sunflower seed oil (pharmacokinetic research). Med Parazitol parazitarnye bolezni 1988, 5:43-46.

20. Shcherbakov AM, Lur'e AA: Clinical trial of the possibility of increasing the bioavailability of mebendazole using sunflower oil in echinococcosis. Meditsinskaia parazitologiia i parazitarnye bolezni 1989, 3:46-49.

21. Mingjie W, Shuhua X, Junjie C, Bin L, Cheng F, Weixia S, Hotez P Albendazole-soybean oil emulsion for the treatment of human cystic echinococcosis: evaluation of bioavailability and bioequivalence. Acta Trop 2002, 83:177-181.

22. Xiao SH, Yang JQ, Wang MJ, Jiao PY, Guo FH, Chai JJ, Jiao W, Hotez P: Augmented bioavailability and cysticidal activity of albendazole reformulated in soybean emulsion in mice infected with Echinococcus granulosus or Echinococcus multilocularis. Acta Trop 2002, 82:77-84.

23. Dzhabarova VI, Veretennikova NL, Kovrova EA: Experimental chemotherapy of echinococcosis. 13. The effect of mebendazole in combination with a vegetable oil on the larval cysts of Echinococcus multilocularis and the reaction of the infested host to long-term administration of the preparation. Meditsinskaia parazitologiia i parazitarnye bolezni 1994, 1:26-29.

24. Chai J, Menghebat, Jiao W, Sun D, Liang B, Shi J, Fu C, Li X, Mao YD, Wang $X L$, Dolikun G, Wang YC, Gao FH, Xiao SH: Clinical efficacy of albendazole emulsion in treatment of 212 cases of liver cystic hydatidosis. Chin Med J (Engl) 2002, 115:1809-1813.

25. Chai JJ, Menghebat, Jiao W, Sun DY, Liang B, Shi JC, Fu C, Li X, Mao YD, Wang XL, Dolikun G, Wang YC, Gao FH, Xiao SH: Observations on clinical efficacy of albendazole emulsion in 264 cases of hepatic cystic echinococcosis. Parasitol Int 2004, 53:3-10.

26. Xiao SH, You JQ, Jiao PY, Guo HF: Studies on the effects of mebendazole, albendazole and their metabolites in an experimental therapy of mice infected with secondary cysts of Echinococcus granulosus. Endem Dis Bull 1990, 5:11-19.

27. Xiao $S H$, Yang YQ, You JQ, Shen BG, Jiao W, Chai JJ: Effects of benzimidazole compounds on mice infected with secondary cysts of Echinococcus granulosus. Chin Med J (Engl) 1994, 107:521-532.

28. Chiba Y, Kohri N, Iseki K, Miyazaki K: Improvement of dissolution and bioavailability for mebendazole, an agent for human echinococcosis, by preparing solid dispersion with polyethylene glycol. Chem Pharm Bull (Tokyo) 1991, 39:2158-2160.

29. Li Y, Sun DJ, MA D: The pharmacokinetics and relative bioavailability of mebendazole peppets after oral administration. Chin J Hosp Pharm 1999, 19:649-651.

30. Luo L, Sun DJ, Miao AD, Wang PF: Pharmacokintic study of $\beta-C D$ mebendazole in rabits. Northwest Pharmaceut J 2000, 15:118-119.

31. Dawson M, Watson TR: The effect of dose form on the bioavailability of mebendazole in man. Br J Clin Pharmacol 1985, 19:87-90.

32. Daniel-Mwuambete K, Ponce-Gordo F, Torrado J, Torrado S, Cuesta-Bandera C: Effect of two formulations of benzimidazole carbamates on the viability of cysts of Echinococcus granulosus in vivo. Parasite 2003, 10:371-373.

33. Xue HX, Mo HM, Sun DJ: The effect of trial treatment mebendazole dazole pellet on secondary hydatid cyst. Endem Dis Bull 2000, 15:11-14. 
34. Xiao SH, Yang YQ, Guo HF, Zhang CW, Jiao PY, You JQ, Jiao W: Effect of mebendazole, albendazole and albendazole sulfoxide on glycogen contents of Echinococcus granulosus cysts in infected mice. Acta Pharmacol Sin 1990, 11:546-549.

35. Luder PJ, Witassek F, Weigand K, Eckert J, Bircher J: Treatment of cystic echinococcosis (Echinococcus granulosus) with mebendazole: assessment of bound and free drug levels in cyst fluid and of parasite vitality in operative specimens. Eur J Clin Pharmacol 1985, 28:279-285.

36. Witassek F, Burkhardt B, Eckert J, Bircher J: Chemotherapy of alveolar echinococcosis. Comparison of plasma mebendazole concentrations in animals and man. Eur J Clin Pharmacol 1981, 20:427-433.

37. Li HT, Shan JY, Shao YM, Tuergan A, Ayifuhan A, Ran B, Wen H: Clinical effect and safety of liposomal-albendazole and tablet-albendazole for the treatment of human cystic echinococcosis. Zhonghua gan zang bing za zhi 2011, 19:532-536.

38. Ammann RW, Eckert J: Cestodes. Echinococcus. Gastroenterol Clin North Am 1996, 25:655-689

39. Venkatesan P: Albendazole. J Antimicrob Chemother 1998, 41:145-147.

doi:10.1186/s13071-014-0589-0

Cite this article as: Liu et al: An alternative mebendazole formulation

for cystic echinococcosis: the treatment efficacy, pharmacokinetics and safety in mice. Parasites \& Vectors 2014 7:589.

\section{Submit your next manuscript to BioMed Central and take full advantage of:}

- Convenient online submission

- Thorough peer review

- No space constraints or color figure charges

- Immediate publication on acceptance

- Inclusion in PubMed, CAS, Scopus and Google Scholar

- Research which is freely available for redistribution 